\title{
Environmental Smog Control Costs and proceeds of Oil and Gas Conglomerates
}

\author{
BY
}

Fadenipo, Adenike Adesola

Department of Accounting, Faculty of Management Sciences, University of Calabar,

P.M.B. 1115, Calabar, Cross River State, Nigeria.

horshinaiki@yahoo.com

Ogenyi, John Oboh

Department of Accounting, Faculty of Management Sciences, University of Calabar, P.M.B. 1115, Calabar, Cross River State, Nigeria.

johnobohognyi@gmail.com

Nwafor Chidi Benson

Department of Accounting, Faculty of Management Sciences, University of Calabar, P.M.B. 1115, Calabar, Cross River State, Nigeria.

chidibenson@yahoo.com

\&

Okoi, John Obono.

Department of Accounting, Faculty of Management Sciences, University of Calabar, P.M.B. 1115, Calabar, Cross River State, Nigeria.

Johnokoi75@gmail.com 


\begin{abstract}
:
The study was carried out to analyse cost implications of environmental smog control costs on the proceeds of oil and gas conglomerates. Panel data were collected and organized from financial statements of selected conglomerates. Data were analysed using ordinary least square of multivariate analysis. Empirical findings revealed that environmental smog control costs have significant effect on the proceeds of the conglomerates investigated. Thus the study suggested and acclaimed that conglomerates should ensure that smog management and controls policies are formulated and implemented to avoid projecting a bad image of the establishment which could lead to loss of goodwill and reduce proceeds in the long run, there should also be effective regulations that will lead to adequate cost disclosure and appropriate financial performance reporting.
\end{abstract}

Keywords: Conglomerates, Control, Costs, Environmental, Gas, Oil, Proceeds, Smog 


\section{Introduction}

A conglomerate's proceeds are dependent on the type of businesses it operates, and it is involved with risks and these risks constitute a consequential determinant of the performance in business operational efficiency. This occurrence affects firms' performance which leads to higher returns (Karambu \& Joseph, 2016). The primary aim of any profit making organisation is to maximize profit, however, their expectation in the area of environmental and other responsibilities is paramount as the management needs to take both proactive and reactive steps to prevent or ameliorate the undesirable outcomes of the activities on the environment. This is important due to the concern that the environment is perceived to have serious operating opportunity cost implications on the proceeds of a firm and also loaded with other responsibilities (Babbie, 2013; Asuquo, Dan, Odey, Linus, Uklala, \& Tapang, 2021). The outcome on environmental pollutant organisations are required in having additional responsibility when securing, formulating a good environment with such programmes that would improve beneficiaries of the community and shareholders' expectations. Buskirk, Green and Rodger (1998), posit that environment is concerned with various activities. For instance, a man could be crippled and incapacitated when not making a wise decision, as an addendum environment plays a catalytic impact on the livelihood of humans. The problem of land degradation, water desecration and air contamination are due to pollution which has globally brought about problems of environmental studies in the measurement of pollution. The country has suffered from lack of intensive research dealing with environmental and social issues until recently. In the past, organizations were ignoring issues in the environment (Murphy 2002). Oil spillages, air smog substances and other waste resources were problems that affected the growth of the economy. It is known that these waste products are dangerous on the ecosystem and the society at large. According to Awasthi (2009), organisations provide a conducive environment with cost in order to determine success or failure. There have been concern over ecological accounting system in the twentieth century and this have enhanced the system and behaviour of companies to gain attention and it has also generated arguments among various stakeholders (Beckman 2003).

Environmental smog plays a crucial role in accounting to clearly, articulate social responsibilities, commitment of effluence generating entities/companies to have their corporate environmental disclosures which aid financial boards like international chamber of commerce. Also international standards of accounting come up with decisions standards to aid their basis of reporting. These standards overwhelm the position of operators in an environment and can control or affect behavioural status. Business organisations of oil and gas industry in Nigeria depicts they undermine environmental and social responsibilities with a supposed mind-set that corporate goals can be achieved even if such responsibilities are encountered with serious degradation in the environment, like destruction to aesthetic substance of water, land and natural beaches as a result of high magnitude of oil spills; loss of marine fauna and flora, alteration of the ecosystem which have resulted in climate change, species extermination, delay in biotic succession of the ecosystem and reduction of aquatic resources. Due to these challenges and many others, some organizations are consolidated with sustainability and it could develop business activities to enhance environmental conservation efforts. Marsh and Grossa (1996) posit that real costs are involved with land, ecosystem etc. as a result of pollutant company. These cost determine some factors like production activities in the determination of the total production cost. This approach assesses accountability, decision making processes and generally, the interrelationship between reporting entity, and its environment. When there is an effective management and control, environmental performance will be improved and be of significant benefit to the health of the people within pollutant environment as well as improved business profitability. 
Researchers such as Manby, (2003); Teresa, (2006); Kobboon, (2008); Ngwakwe (2009) conducted studies that affected environmental degradation of oil pollution and spillages while some have reported causes and effects of oil and gas industries on a particular environment. Recently in year 2021, the supreme court of United Kingdom Parliament square in London upheld an appeal case of some Niger Delta communities' representatives in Nigeria over a suit against the Royal Dutch Shell PLC on a case of oil pollution and spillage in the region. The role played by corporations in environmental pollution control is embedded on financial performance. The sensitization in environmental sustainability can be reflected by various environmental management mechanisms implemented by organizations around the world. Big organisations handle environmental issues by identifying and estimating the environmental benefits, costs, assets, liabilities and investments. In Nigeria, no research on this area has involved smog prevention and control, waste control costs and compensating system, like litigation costs as a regression. To bridge this gap, a comprehensive study anchoring costs implication of smog management and control on profitability particularly upstream sector is warranted which will be of interest to the host communities, the management and the government. The study aimed: To ascertain effect of pollution prevention and control costs on the profitability, to evaluate the relationship between waste control cost and profitability, and to determine the extent at which litigation and compensation cost influence the proceeds.

\section{Literature and theoretical framework}

\subsection{The stakeholders' theory}

This theory was propounded by Freeman in 1980s. It is concerned with regulations, control morals and values in management either internally or externally. Stakeholder's theory addressed the principle of what or who really counts. Also interest of management are affected by the activities of the firm. The focus of that interest is anchored on stakeholders. This theory captures profit maximization in relation to the organization and operationThe stakeholder theory is a significant theory as it harmonized resource based view without leaving out the socio-political view. In view of the stakeholder theory phenomena, Werhane, Patricia and Edward (1999) posit that stakeholder is an individual having a relationship with the firm towards goals

\subsection{Environmental sustainability theory}

This theory was postulated by Thomas Malthus in 1800. The environmental sustainability theory states that in reaping from nature's bounty no one loses sight on the note that nature's provision was made in 'total once' for both present and future generation, IUCN 1980. It emphasized the importance of the natural environment economic development and its sustenance (Anijah-obi, 2001). John 2001 posited that issue of sustainable development and environment are interrelated and often mutually reinforcing. The UN agenda for development posit on development as human right which is the foundation for development and environment is the basis for sustainability. One sees that there can be no meaningful progress or developments if the environment could not be sustained and every business organization strives in an environment. At a fundamental level there is a provision for physical system that leads to human life existence (Awasthi, 2009)

\subsection{Environmental Cost-benefit theory}


The theory seeks to analyze effectiveness of cost on benefits. This theory buttresses the economic appraisal of policies that have the deliberate aim of improving the environment or actions that might adversely affect the environment. The theory envisages the impact of natural environmental policies pertaining to pollution etc. Dawkins (2003) stated that the essence of environmental cost benefits theory is on social benefits which tend to occur at different points in time. Different techniques such as Fiscal Impact Analysis (FIA), CostEffective Analysis (CEA), Social Returns on Investment (SROI) and Economic Impact Analysis (EIA). The main concern is the contentious issue of matching the expenditure incurred on each environmental activity with the benefits associated with it.

\subsection{Conceptual framework}

\subsubsection{Management and control of environmental smog}

In every organization there is environmental issues that affect businesses such as pollution which is emanated from risk that could be properly handled. Smog is the process where businesses are harmful through degradation in an active environment, it involves air etc. Air aspect is defined as the existence of any contaminant of the air in the atmosphere. Air contaminants are detrimental to the health of humans, animals, plants or other living creatures in the environment through gaseous substance in the atmosphere. Soil contaminant is involved with oil and organic solvent as source of soil contamination and is very harmful to the living organisms. Water Smog refers to water contamination or adulteration to the biological, chemical or physical qualities of water resources. It could be in form of any domestic sewage discharge or industrial wastes discharge of any liquid, solid or gaseous elements into water directly or indirectly which could make such water detrimental or harmful to safe health of the environment be it to humans, agricultural products, animals or aquatic creatures. Smog prevention and control costs are contingent costs allocated for avoiding and managing environmental degradation due to smog caused by organisation activities. They include costs to forestall the occurrence of pollution and managing the eventual occurrence. Litigation and Compensation costs are degradation linked with pollution and compensations costs for the people affected by the organisation pollution activities. Waste control costs are costs incurred during wasteful resources which include storage, way it is collected, transported and disposed. Profitability is the process where an organisation is capable in making returns which the leftover of income on all expenses and relevant costs associated with the business have been paid.

\subsubsection{Cost implication of environmental smog control costs on proceeds.}

Pollution control costs are classified under environmental or ecological costs. It helps in reducing damages and conserve environmental resources. They include pollution prevention costs, clean-up and remediation cost (waste control costs), litigation \& compensation cost. According to Stefan, Van, Tudoran \& Lahteenmaki (2013), the environmental costs accrued five percent what is sold as a bottleneck to profits. Environmental pollution can be accounted for physically or monetarily. The physical accounting includes the physical accounting of pollution discharge and oil spillages (Nagle, 1994). Monetarily, this pollution is made up of monetary cost and environmental degradation cost which founded on both accounts. Investments could be made on an equipment to reduce environmental hazardous emission and pollution; such investment is classified as environmental cost. Whereas this particular capital expenditure is meant to improve the company's production and utilizing their capacity. In the production process, toxics and wastes are processed and they are released and the way of handling such products are managed and controlled internally, or is better handled by external waste management companies. Managing and controlling such pollution cases are 
affected are by costs. Tsoutsoura (2004) viewed that management system enhances long run performance when there is competitive performance efficiency. The perception is slightly different in the developing countries, majorly due to ineffective government laws and regulations combined when there is no coordinated groups and customers' awareness or sensitizations to influence organizational behaviour. These costs are well controlled through effective and operational cost reduction systems that are a highly feasible toward operational and managerial rationalization of Management System expenditures. These cost produces a guide on financial performance. The level of costs influences profitability as determined by other factors like pollution prevention and control cost, waste control costs, litigation and compliance cost. The implication of these factors are analysed on profitability proxy by total returns on assets.

\section{Conceptual model}

Pollution management and control costs

\section{Profitability}

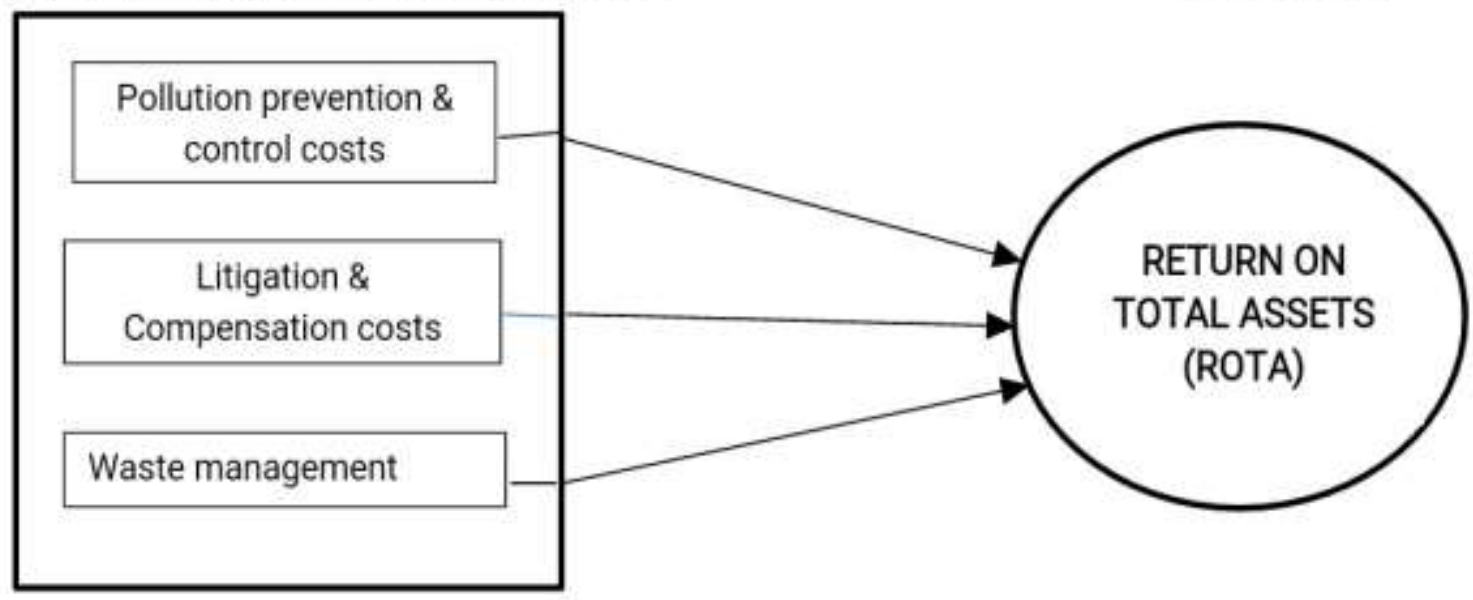

Source: Researchers, 2021

Fig. 1. Conceptual model on environmental smog management and control costs on proceeds

\subsection{Empirical Framework}

Asuquo (2012) conducted a study on environmental policies and performance of some selected oil and gas companies in Nigeria. It was proven that environmental friendly policies have a significant relationship with the firms' profitability and concluded that environmental protection and management costs positively influenced the profits of environmental friendly entities. Ifurueze, Lyndon and Bingilar (2013), investigated environmental cost on performance in oil companies in Nigeria and found that environmental cost has a significant impact on performance. The study recommended that management could have an articulated system and to ensure a conducive atmosphere that is peaceful. Hassel, Nilsson and Nyquist (2005) examined environmental cost information on market value in Sweden. It was discovered that companies are eroded with gradual depletion in earnings. Epstein (2008) investigated environmental degradation and cost of water and land. Shehu (2014) evaluated environmental expenditure on the performance of companies in Nigeria (1999-2010). Multiple regression technique was used and the result revealed that environmental expenditure positively affected the performance. He recommended that the management organization should improve expenditure in their host community in order to boost their 
output. Effiong and Etowa (2012), examined the degree of influence of oil spillage and gas flaring costs on life expectancy rate of the Niger Delta people of Nigeria. The descriptive survey research method was used to select forty oil and gas producing local government areas from the nine states of the Niger Delta region. Data on oil spillage rate, gas flaring rate, oil spillage volume, gas flaring volume, oil spillage cost and gas flaring cost were obtained from NNPC, the oil and gas companies and the Central Bank of Nigeria for the thirty years studied. Data for life expectancy were obtained from the United Nations Common Database for the thirty years. The study revealed a total oil spillage and gas flaring revenue loss of US $\$ 175,795,811$ or $\mathrm{N} 20,671,321,766.00$ with a mean life expectancy rate of 49.12 years between 1979 and 2008 with an insignificant correlation between life expectancy rate and the costs of oil spillage and gas flaring ranging between $1.8 \%$ and $5.2 \%$ but a significant impact of oil spillage and gas flaring activities on socio- economic conditions and poverty rate of the people of the Niger Delta region of Nigeria for the years studied. Based on these results, the study recommended that government should enact mandatory legislations for oil and gas prospecting companies to establish Oil and Gas Compensation Fund to control the frequency of oil spillage and gas flaring in the Niger Delta region of Nigeria. Effiong, Oti, and Akpan, (2019), observed that a noticeable gap exists between the company and the stakeholders when the company focuses on single bottom reporting that only shows profitability at the expense of environment and society. Secondary data were from the NSE Fact Book and Annual Reports of studied companies quoted in NSE. A disclosure checklist of GRI guidelines was used while employing the ex post facto design. All the twelve quoted Oil and Gas companies were studied for ten years with descriptive statistics and panel data regression analysis employed. The findings showed that economic, social and environmental performance disclosures significantly affect economic value, market value and cash flow returns on investment. These results confirm that corporate strategies of reporting the organization's footprints on the basis of environment, social and economic conditions of stakeholders significantly maximize shareholders' value. Effiong, Ahakiri, Fadenipo and Okoi, (2021), considered the co-integral consequences of Triple Bottom Line financial reports of listed hydrocarbon companies on their financial outlooks. It was conducted to evaluate the crystalized correlation of responsible hydrocarbon companies on their financial fortunes. The study employed the expos facto design where secondary data were obtained from the annual reports of the listed hydrocarbon companies on the floor of the Nigerian Stock Exchange. The least-square multiple linear regression analysis methods were employed to establish the degree of financial crystallization consequential to the adoption of the triple bottom reporting format. Social, economic, and environmental reports of the studied listed hydrocarbon companies were co-integrated with the returns on assets of the companies, to establish the level of crystallization of the explanatory variables with the response variable. The crystallized results revealed that economic disclosure and environmental disclosure have limited significant crystallization characteristics on the returns on assets, while social disclosure showed significantly positive crystallization characteristics with returns on assets of the studied companies. Arising from these findings, the study recommended that a mandatory reporting framework be put in place for hydrocarbon companies listed on the floor of the Nigerian Stock Exchange to encourage sustainability reporting

\section{Methodology}

3.1 Research design: Ex-post facto design was employed, as it was the appropriate design for the investigation. 
3.2 Nature and source of data: To achieve this objective, annual data for the period 20102019 of ten conglomerates operating were selected. Content analysis as a tool is considered as an appropriate tool of study because the actual environmental smog costs of the conglomerates under review are majorly disclosed descriptively in the financial statement. The organizations were however analysed based on disclosures from their sustainability report of the environmental smog control activities. These disclosures are used to analyse their accountability or responsibility to their environment and the impact of such on their profitability. The data generated were subjected to qualitative and quantitative analysis. Ten companies whose activities majorly affect the Nigeria environment are however selected as sample to represent the population. The companies were selected based on availability of reports from NSE records. These are Total, Nigerian Agip Coy Ltd (Eni), Chevron Plc, Mobil Producing Nig., Oryx Petroleum Ltd, Shell Petroleum Development Company, Forte Oil Plc (Ardova Plc), Lekoil Plc, Svenska Petroleum Exploration, Oando Plc. For this study, systematic random sampling was employed in selecting a sample of a population. Secondary data were sourced from their annual reports. Independent variables were measured using dummy variables that is; content analysis coding was adopted. ' 0 ' and ' 1 ' were used for disclosure and non-disclosure of the environmental smog and associated costs. Also ' 0 ' and ' 1 ' were used to determine whether or not the annual report disclosed that these costs are incurred even though the actual costs are not visible in the financial analysis. This method was adopted due to challenge of not disclosing their actual environmental, smog and associated costs in the analysis of the financial statement. They are most time disclosed under the director's report descriptively; this pose a major limitation to this research study. In other to test on smog management and control on profit of conglomerates, the regression model below was adopted:

$\mathrm{ROTA}=\mathrm{f}(\mathrm{SPC}+\mathrm{LCC}+\mathrm{WMC})$

Where:

ROTA $=$ Return on Total Assets represents the profitability (Dependent variable)

Independent variables are:

Smog Prevention and Control costs (SPC)

Waste Control Cost (WCC)

Litigation and compensation cost (LCC)

As a panel data, the statistical technique used to analyse the data was multiple linear regression technique (Onodugo, Ugwuonah \& Ebinne 2010). In multiple regression analysis, the coefficient of multiple correlations known as the multiple $\mathrm{R}$ and the coefficient of multiple determination $\left(R^{2}\right)$ are employed to show how variables are related. The $R^{2}$ denotes the proportion of variable in the criterion caused by the predictor, the $R^{2}$ adj reduces the proportion of the accounted variation to an expected level when using the same model in a sample from the same population. Multiple regression analysis is a test of goodness of fit (Nworgu, 1991).

\section{Results and discussion}

4.1 Summary of results

Table 1: Model summary

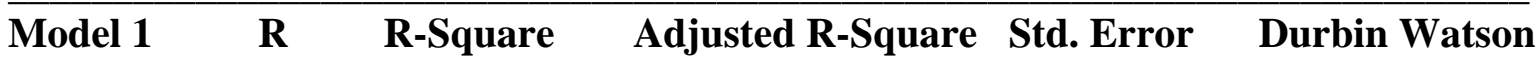


a. Predictors: (Constant) Smog Prevention Control Costs, litigation cost/compensation cost waste management and control cost

b. Dependent variable: Return on total assets

Source: Authors' computation, 2021

Table 2: $\quad$ ANOVA

\begin{tabular}{lllccc}
\hline Model 1 & Sum of Squares & DF & Mean of Squares & F & Sig. \\
Regression & $\mathbf{. 0 4 0}$ & $\mathbf{3}$ & $\mathbf{0 1 3}$ & $\mathbf{3 . 1 8 8}$ & $\mathbf{. 0 2 7}$ \\
Residual & $\mathbf{. 4 0 1}$ & $\mathbf{9 6}$ & & & \\
Total & .441 & $\mathbf{9 9}$ & & &
\end{tabular}

a. Predictors: (Constant) Smog Prevention Control Costs, litigation cost/compensation cost waste management and control cost

b. Dependent variable: Return on total assets

Source: Authors' computation, 2021

Table 3: Coefficients

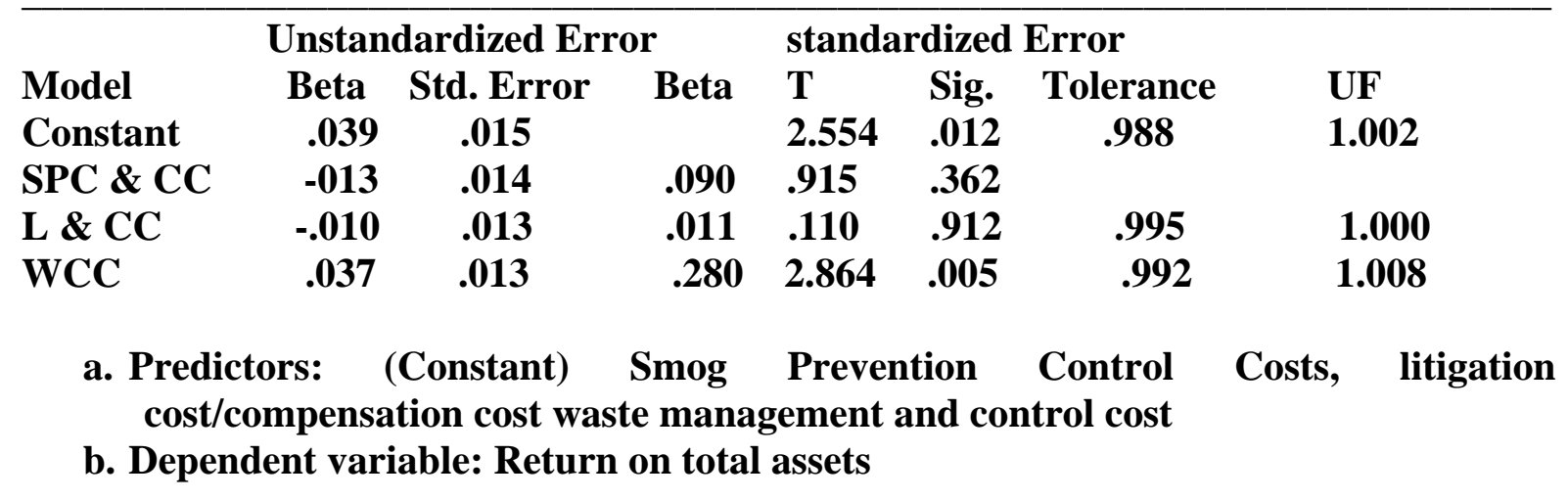

Source: Authors' computation, 2021

The result of the estimation model as presented. Multiple linear regression technique is used for the estimation of the Error Correction Model (ECM). The R square is approximately $* 0.38$ and it indicates that 38 per cent of the systematic variation in ROTA is explained by short term movements in the independent variables included in the ECM; thus implying that the model has a fairly strong predictive power. Moreover, the F-statistic is 0.027 which indicates the model is statistically significant. This depicts that increase in the environmental pollution management and control costs have significant effect on the proceeds. However, there is a weak relationship between WMC and ROTA and negative relationship between SPC and LLC and ROTA. It can be seen that only the coefficient of WMC is significant at 0.5 per cent. The probability values of all the other regressors are greater than 5 per cent $(\mathrm{p}>$ 0.05). The result also shows a Durbin-Watson result of 2.198 which is approximately 2. This 
is the conventional acceptable level for the result, it indicates the absence of autocorrelation in the independent variable data.

\subsection{Test of hypothesis one}

The result shows that smog prevention \& control cost (SPC) have no effect on profitability. The coefficient of SPC is negative and not significant (Estimated coefficient $=-0.013, \mathrm{p}=$ 0.36). The result indicates that an incremental change in SPC will bring about 0.01 unit decrease in ROTA. Therefore, the null hypothesis that SPC has no significant effect on profitability is accepted.

\subsection{Test of hypothesis two}

The result shows that litigation \& compensation costs (LCC) have no effect on profitability. The coefficient of LCC is negative and not significant (Estimated coefficient $=0.010, \mathrm{p}=$ 0.91). The result indicates that an incremental change in LCC will bring about 0.01 unit decrease in ROTA. Therefore, the null hypothesis that LCC has no significant effect on profitability is accepted.

\subsection{Test of Hypothesis three}

The regression result shows that waste control costs (WMC) have significant effect on profitability. The coefficient of WMC is positively significant (Estimated coefficient $=0.037$, $\mathrm{p}=0.005)$. The result indicates that an incremental change in WMC will bring about 0.037 unit increase in ROTA. Therefore, the null hypothesis that WMC has no significant effect on profitability is rejected.

\subsection{Summary discussion of findings}

The findings showed that smog prevention \& control costs (SPC) have a negative and insignificant effect on proceeds. SPC affects the organizations proceeds negatively, although the effect is seen to be insignificant. Environmental cost has a negative and insignificant impact on the firms. Litigation and compensation costs (LLC) have a negative and insignificant effect on proceeds. Waste control costs (WMC) with a positive and significant impact on proceeds. Other explanatory variables and firms' performance were statistically significant.

\section{Conclusion}

The study portrays that companies that do not consider their responsibility of smog and prevention control, with proper disclosure measures could be risky in having goodwill and revenue through the litigations and compensation payments. This expense is averted with precautionary measures such as prevention controls which are taken on time and when these companies disclose enough information that will aid the organization achieve its goals and objective.

\subsection{Recommendations}

The following recommendations are made: Oil and gas conglomerates should ensure that smog control policies are formulated and implemented to avoid projecting a bad image of the conglomerate which could lead to loss of goodwill and reduce profitability in the long run, there should also be regulatory enforcement of these policies that will lead to; Reporting environmental and contamination/smog related matters should be given priority, oil and gas companies should endeavour to create a positive impact on the activity of annual reports and accounts; Proper resource allocation and classification between environmental smog and other costs will have adequate cost direction to aid in developing proxies of sustainability; Oil 
and gas companies should ensure that Expenditure on environmental pollution costs should capture social responsibility policy effectively in order to meet stakeholders' expectations; and Measures should be taken to avoid smog induced litigations. The companies should comply with these laws as regulated by oil and gas industry regulatory agencies.

\section{Conflict of interest: Nil}

\section{Acknowledgements}

The Authors honestly recognised and express gratitude to all the persons who have contributed in one way or the other toward the successful compilation of this research manuscript.

\section{References}

[1] Asuquo, A. I. (2012). Environmental friendly policies and their financial effects on corporate performance of selected oil and gas companies in Niger Delta region of Nigeria. American International Journal of Contemporary Research, 2(1), 118-125.

[2] Asuquo, A. I., Dan, N. O., Odey, I. O., Linus, M. U., Uklala, A. P., \& Tapang, A. T. (2021). Environmental operations review and stakeholders' wealth of extracting firms: Evidence from Nigeria. International Journal Financial Research, 12(3, Special issue), 172-180. 
[3] Anijah-Obi, F. N. (2001). Fundamentals of environmental education and management, University of Calabar Press.

[4] Arong F. E., Ezugwu C. I., \& Egbere M. I. (2014). Environmental cost management and profitability of oil sector in Nigeria. Journal of Good Governance and Sustainable Development in Africa, 2(2), 32-40.

[5] Awasthi, A. K. (2009). Environmental issues in audit. http://www.aud.ecosy.com/environmental accounting issues/concept.

[6] Babbie, E. (2013). The practice of social research. Wadsworth Cengage Learning.

[7] Bassey E. B., Sunday O. E., \& Okon E. E. (2013). The impact of environmental accounting and reporting on organizational performance of selected oil and gas companies in Niger Delta region of Nigeria. Research Journal of Finance and Accounting, 33(3), 56-71.

[8] Chukwuma, R. N. (2015). Influence of environmental costs on the performance of some selected quoted manufacturing companies in Nigeria. https://www.projectreserve.com

[9] Dawkins, C. J. (2003). Regional development theory: Conceptual foundations, classic works, and recent developments. Journal Of Planning Literature:

https://www.researchgate.net/publication/2453ww

[10] Effiong, S. A., Ahakiri, F. I., Fadenipo, A. A., \& Okoi, J. O. (2021). Cointegral Crystallization of triple bottom financial reports and the performance of hydrocarbon companies. Journal of University of Shanghai for Science and Technology ISSN: 1007-6735, 23(11), $500-515$.

[11] Effiong, S. A., Oti, P. A. \& Akpan, D. C. (2019). Triple bottom line reporting and shareholders' value in oil and gas marketing firms in Nigeria. Academy of Accounting and Financial Studies Journal, 23(5), 1-16.

[12] Effiong, S. A., \& Etowa, U. E. (2012). Oil spillage cost, gas faring cost and life expectancy rate of the Niger Delta people of Nigeria. Advances in Management and Applied Economics, 2(2), $211-228$

[13] Elkington, J. (1997). Cannibals with forks: Triple bottom line of 21st century business. New Society Publishers.

[14] Epstein, M. (2008). Making sustainability work: Best practices in managing and measuring corporate social, environmental, and economic impacts. Greenleaf.

[15] Freeman, A. B. (1983). Toward an epistemology for radical accounting: Beyond objectivism and relativism. Critical Perspectives on Accounting, 6(1), 485-496.

[16] Friedman, M. (1980). Capitalism and Freedom. University of Chicago Press.

[17] GRI. (2001). The global reporting initiative sustainability reporting guidelines. Global reporting initiative. https://www.globalreporting.org/standards

[18] Hart, S. L. (1997). Beyond greening: Strategies for a sustainable world. Harvard Business Review. 
[19] Hassel, L., Nilsson, H., \& Nyquist, S. (2005). The value relevance of environmental performance. European Accounting Review, 14(1), 41-46.

[20] IFAC. (1998). Environmental management in organisations: The role of management accounting, financial and management accounting committee. International Federation of Accountants. https://www.ifac.org

[21] 1FAC (2005). International guidance document: Environmental management accounting. International Federation of Accountants. https://www.ifac.org

[22] Ifurueze, M. S. K, Lyndon. M., \& Bingilar, B. (2013). Impact of environmental cost on corporate performance of oil companies in Niger Delta States of Nigeria. Journal of Business \& Management. 2(2), 23-30.

[23] Institute of Chartered Accountants of Nigeria (ICAN) (2009). Costing and quantitative techniques. VI publishers.

[24] Karambu, K. G., \& Joseph, M. W. (2016). Effect of corporate environmental disclosure on financial performance of firms listed at Nairobi securities exchange, Kenya. International Journal of Sustainability Management and Information Technologies, 2(1), 1-6

[25] Konar, S., \& Cohen, M. (2001). Does the market value environmental performance? Review of Economics and Statistics, 83(2), 281-309

[23] Kobboon, C. (2008). Corporate social environmental disclosures within the Canadian mining industry: The adoption of the global reporting initiative. http://www.ats.ucla.edu/stat/sp/webbooks/reg.htm

[26] Malarvizhi, P., \& Ranjani, M. (2016). Link between corporate environmental disclosure and firm performance: Perception or reality? Review of Integrated Business \& Economic Research, 5(3), 117-125.

[27] Manby, B. (2003). Corporate social responsibility in the Ogoni crisis: Case study for the Carnegie council and ethics on international affairs. Shell. http://www.scf.usc.edu/cstern/Shell

[28] Marsh, W. M., \& Grossa, J. M. (1996). Environmental geography, science, land use and earth systems. John Wiley and Son Inc.

[29] Murphy, C. J. (2002). The profitable correlation between environmental and financial performance: LightGreen. http://www.lightgreen.com/files/pc.pdf

[30] Nagle, G. (1994). Business Environmental Cost Accounting Survey: Global Environment Management Initiative 1994 Conference Proceedings. Arling VA.

[32] Ngwakwe, C. (2009). Environmental responsibility and firm performance in Nigeria. International Journal of Social, Education, Economics and Management Engineering, 2(10), 60 - 67.

[33] Nwaiwu, N. J., \& Oluka, N. O. (2018). Environmental cost disclosure and financial performance of oil and gas in Nigeria. International Journal of Advanced Academic Research, Financial Management, 4(2), 2488-2849 
[34] Nworgu, B. G. (1991). Educational research: Basic issues and methodology. Wisdom Publishers.

[35] Onodugo, V. A., Ugwuonah, G. E., \& Ebinne, E. S. (2010). Social science research: Principles, methods and application. EL' DEMAK Publishers.

[36] Osuala, E. C. (2005). Research Methodology. New Generation Books.

[37] Sanda, A., Mikaila, A. S., \& Garba, T. (2005). Corporate governance mechanisms and firm financial performance in Nigeria. African Economic Research Consortium 14(9), 225-230.

[38] Shehu, U. H. (2014). Environmental costs and firm performance: Evidence from quoted oil and gas companies in Nigeria. Seminar Presentation in Accra, Ghana.

[39] SPDC. (1995). Shell and the Nigerian environment. Public Affairs Department: Shell Petroleum Development Company. https://www.shell.com.ng/

[40] Stead, W. E., \& Stead, J. G. (1992). Management for a small planet: Strategic decision making and the environment. Sage Publications.

[38] Stefan, V., Van, H. E., Tudoran, A. A., \& Lahteenmaki, L. (2013). Avoiding food waste by Romanian consumers: The importance of planning and shopping routines. Journal of Cleaner Production 182 (2), 978-991

[41] Teresa, T. Y. (2006): Environmental disclosure in Hong Kong, with comparison to United Kingdom and Canada. Accounting Auditing \& Accountability Journal, 15(3), 344-371.

[42] Tsegba, N. I. (2011). A synthesis of theories relevant to corporate governance and social responsibility. Journal Publication Department of Accounting, Bayero University Kano, Nigeria, 5(1), 70 - 87.

[43] Tsoutsoura, M. (2004). Corporate social responsibility and financial performance. Applied Financial Project Haas School of Business. https://haas.beckeley.edu/

[44] Werhane, H., Patricia, R., \& Edward, F. (1999). Business ethics: The state of the art. International Journal of Management Reviews, 1(1), 1-16.

[45] Wikipedia, (2009). Social responsibility. Wikipedia. http//en.wikipeadia.org/wiki/socialresponsibility

[46] World Bank, (1995). Implementing geographic information systems in environmental assessment. Environmental Assessment Sourcebook: Update No 9. World Bank. 